\title{
Pengaruh Penambahan Ekstrak Kecambah dan Kadar Gula Pasir Terhadap Karakteristik Nata De Soya dari Limbah Cair Tahu
}

\section{(Effect of Addition of Sprout Extract and Sugar Content on the Characteristics of Nata de Soya From Tofu Liquid Waste)}

\author{
Dewi Lestari ${ }^{1}$, Siti Fatimah ${ }^{2 *}$ \\ ${ }^{1,2}$ Program Studi Teknik Kimia, Fakultas Teknik, Universitas Muhammadiyah Surakarta - Jl. A. Yani, \\ Mendungan, Pabelan, Kec. Kartasura, Kabupaten Sukoharjo, Jawa Tengah 57169
}

\begin{tabular}{l} 
ARTICLE INFO \\
\hline Article history \\
Received : 24 Juli 2021 \\
Revised : 20 September 2021 \\
Accepted : 22 September 2021 \\
DOI : \\
https://doi.org/10.33366/rekabua \\
na.v6i2.2614 \\
Keywords : \\
acetobacter xylinum; \\
green bean; nata de soya; \\
sugar; whey. \\
*e-mail corresponding author : \\
sf120@ ums.ac.id
\end{tabular}

\section{PENERBIT}

\section{UNITRI PRESS}

J1. Telagawarna, TlogomasMalang, 65144, Telp/Fax: 0341-565500

\section{(c) (i) (?)}

This is an open access article under the Creative Commons Attribution-ShareAlike $\quad 4.0$ International License. Any further distribution of this work must maintain attribution to the author(s) and the title of the work, journal citation and DOI CC-BY-SA

\section{ABSTRAK}

Pembuatan nata de soya menggunakan bahan kimia tambahan berupa Zwavelzure Ammoniak (ZA) yang berfungsi sebagai sumber nitrogen. ZA berbahaya jika dikonsumsi dalam batas maksimum sehingga perlu diganti dengan bahan alami. Kecambah adalah salah satu bahan alami yang mengandung nitrogen organik. Kecambah kacang hijau inilah yang akan digunakan sebagai sumber nitrogen untuk menggantikan fungsi dari ZA. Penelitian ini bertujuan untuk mengetahui pengaruh penambahan ekstrak kecambah kacang hijau dan gula sebagai karakteristik nata de soya. Penelitian ini menggunakan metode Rancangan Acak Lengkap (RAL). Didapat hasil uji terbaik kadar air $98,76 \%$, vitamin c $12,68 \%$, rendemen $22,74 \%$, ketebalan $1,1 \mathrm{~cm}$ dan kadar serat kurang dari $4,5 \%$ sesuai Standar Nasional Indonesia (SNI).

\section{ABSTRACT}

The manufacture of Nata de soya uses additional chemicals in Zwavelzure Ammonia (ZA) which functions as a nitrogen source. ZA is dangerous if consumed at the maximum limit, so it needs to be replaced with natural ingredients. Sprout is one of the natural ingredients containing organic nitrogen. This mung bean sprout will be used as a nitrogen source to replace the function of ZA. This study aims to determine the effect of adding green bean extract and sugar as characteristics of Nata de soya. This study is prepared using a completely randomized design (CRD). According to the Standard National Indonesian (SNI), the best test results obtained are $98.76 \%$ water content, $12.68 \%$ vitamin C, $22.74 \%$ yield, $1.1 \mathrm{~cm}$ thickness, and less than $4.5 \%$ fiber content.

Cara Mengutip : Lestari, D., Fatimah, S. (2021). Pengaruh Penambahan Ekstrak Kecambah dan Kadar Gula Pasir Terhadap Karakteristik Nata De Soya dari Limbah Cair Tahu. Reka Buana : Jurnal Ilmiah Teknik Sipil dan Teknik Kimia, 6(2), 112-119. doi:https://doi.org/10.33366/rekabuana.v6i2.2614 


\section{PENDAHULUAN}

Industri tahu menghasilkan produk lain berupa limbah padat dan cair (whey) [1]. Limbah cair ini tidak digunakan lagi tetapi mempunyai kandungan gizi yang cukup untuk olahan pangan. Kandungan whey tahu berupa nitrogen 1,3\%, gula reduksi $1,4 \%$, dan $\mathrm{pH}$ 5. Bahan organik whey tahu terdiri dari protein sebesar $65 \%$, lemak sebesar $25 \%$ dan karbohidrat sebesar 25\% [2]. Kandungan gula dalam whey tahu sekitar $(0,7-0,9 \%)$. Sehingga pembuatan nata perlu penambahan gula sebanyak $10 \%$ volume medium yang digunakan [3]. Gula pasir dapat digunakan sebagai sumber karbon bagi pertumbuhan bakteri saat pembuatan nata [4].

Zwavelzure Ammoniak (ZA) atau urea merupakan sumber nitrogen yang dipakai dalam pembuatan nata tetapi relatif berbahaya jika dikonsumsi dalam batas maksimum 0,5\% [5]. Bahan alami seperti kacang-kacangan dapat digunakan sebagai sumber nitrogen karena memiliki kandungan antara 20-35\% [6]. Kecambah kacang hijau digunakan dalam penelitian ini sebagai nitrogen untuk menggantikan fungsi dari ZA [7]. Whey tahu bisa menjadi salah satu media dalam pembuatan nata yang cukup baik hal ini berdasarkan isi kandungan nutrisi yang dimilikinya. Whey tahu dalam pembuatan Nata lebih bermanfaat dan berpotensial dikarenakan jumlah yang dihasilkan dari pengolahan industri tahu cukup besar sehingga menggurangi kerusakan lingkungan [4].

Maka dari itu peran pemerintah dan peneliti sangat penting dalam memberdaya hasil industri pengolahan tahu. Hal yang dapat dilakukan dengan memanfaat whey tahu menjadi makanan yang bermutu jual, bermanfaat dan sehat bagi masyarakat [8]. Tujuan dilakukannya penelitian untuk mengetahui pengaruh penambahan ekstrak kecambah kacang hijau dan variasi gula pasir pada karakteristik Nata de Soya dari limbah cair tahu. Diharapkan dalam menciptakan Nata de Soya yang berasal dari whey tahu ini menjadi sebuah produk pangan yang bermutu baik serta terdapat nilai jual.

\section{METODE PENELITIAN}

\subsection{Alat}

Alat yang digunakan: aerator, baskom, blender, botol aquades, cawan porselin, corong kaca, desikator, ember, erlenmeyer, gelas beker, gelas ukur, hot plate, jangka sorong, jerigen, kaca arloji, karet hisap, karet gelang, kertas koran, kertas saring, kompor, kondensor, labu ukur, lap, mortar, nampan plastik, neraca analitik, panci, pengaduk kaca, $\mathrm{pH}$ meter, pipet tetes, pipet ukur, pisau, saringan, selang, statif dan toples kaca.

\subsection{Bahan}

Bahan yang digunakan: aquadest, asam asetat/asam cuka (25\%), garam inggris, gula pasir, kecambah kacang hijau, limbah cair tahu, starter nata. 


\subsection{Prosedur kerja}

\subsubsection{Pembuatan Ekstrak Kecambah Kacang Hijau}

Kecambah kacang hijau dicuci bersih kemudian ditiriskan dan dihaluskan dengan blender perbandingan yang digunakan 1:1 ( 680 air : 680 kecambah kacang hijau). Hasil dari pemblenderan disaring menggunakan kain saring hal ini bertujuan untuk memisahkan ampas dengan airnya. Air kecambah kacang hijau ditempatkan dalam baskom.

\subsubsection{Pembuatan Media}

Limbah cair tahu (whey) diukur dengan menggunakan gelas ukur sebanyak $4800 \mathrm{ml}$, disaring menggunakan saringan kemudian dimasukkan kedalam 4 panci. Pada setiap panci berisikan $1200 \mathrm{ml}$ whey dan di masak sampai mendidih $\left(100^{\circ} \mathrm{C}\right)$. Saat perebusan setiap panci ditambahkan ekstrak kecambah kacang hijau masing masing $160 \mathrm{ml}$ dan $180 \mathrm{ml}$ serta garam inggris $6 \mathrm{~g}$, gula pasir $60 \mathrm{~g}$, dan asam cuka (25\%) sampai $\mathrm{pH}$ yang dibutuhkan berkisar antara 3-4 menggunakan indikator $\mathrm{pH}$ universal. Angkat media saat mencapai suhu $100^{\circ} \mathrm{C}$ kemudian tuangkan ke dalam nampan plastik setiap nampan berisi $900 \mathrm{ml}$. Kemudian media di dinginkan sampai suhu ruang dan tutup dengan menggunakan koran agar tidak terjadi kontaminasi.

\subsubsection{Inokulasi}

Media whey tahu yang sudah dingin, ditambahkan starter nata sebanyak $10 \%$ (90ml) pada tiap nampan. Selanjutnya nampan ditutup kembali dengan koran dan dikencangkan menggunakan karet.

\subsubsection{Inkubasi}

Proses inkubasi (proses fermentasi) dilakukan pada suhu ruang $(28-31)^{\circ} \mathrm{C}$ dan dilakukan selama 10 hari pada $\mathrm{pH}$ yang di jaga konstan.

\subsubsection{Karakteristik}

Penelitian ini menggunakan Rancangan Acak Lengkap (RAL). Variabel bebas adalah ekstrak kecambah kacang hijau dan variasi gula. Variabel tergantung adalah kadar air, kadar serat, vitamin c, rendemen, ketebalan. Variabel kontrol adalah pH, suhu, kelembaban, volume limbah cair. Setiap perlakuan di analisis beratnya menggunakan neraca analitik dan jangka sorong untuk mengukur ketebalan dan berat pada nata. Sampel di uji rendemen, di uji kadar air dengan menggunakan metode gravimetri, lalu uji kadar vitamin $\mathrm{C}$ dengan metode iodometri, serta di uji kadar serat dengan gravimetri. Kadar serat merupakan residu dari sampel yang mengandung selulosa dengan sedikit lignin dan pentosan yang dianalisis setelah diasamkan dan dibasakan dengan larutan asam (asam sulfat) dan basa (natrium hidroksida) panas. 


\section{HASIL DAN PEMBAHASAN}

\subsection{Uji Kadar Air}

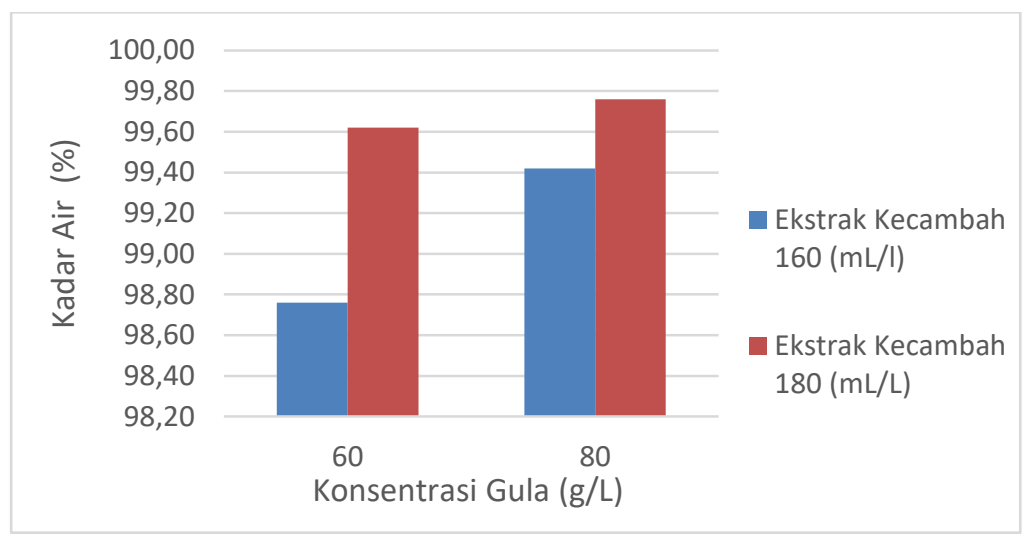

Gambar 1. Uji kadar air pada Nata de Soya

Berdasarkan gambar 1, hasil uji kadar air penambahan ekstrak kecambah kacang hijau dan variasi gula menunjukkan bahwa kadar air terendah pada penambahan ekstrak kecambah kacang hijau $160 \mathrm{ml}$ pada konsentrasi gula $60 \mathrm{~g} / \mathrm{L}$ didapatkan $98,76 \%$ dan $80 \mathrm{~g} / \mathrm{L}$ didapatkan $99,42 \%$. Sedangkan kadar air tertinggi pada penambahan ekstrak kecambah kacang hijau $180 \mathrm{ml}$ pada konsentrasi gula 60 $\mathrm{g} / \mathrm{L}$ didapatkan 99,62\% dan $80 \mathrm{~g} / \mathrm{L}$ didapatkan 99,76\%. Perlakuan terbaik ada pada penambahan ekstak kecambah kacang hijau $160 \mathrm{ml}$ dan konsentrasi gula $60 \mathrm{~g} / \mathrm{L}$.

Faktor ini disebabkan karena kadar air yang tinggi memiliki serat yang lebih rendah, sahingga air mudah masuk karena jaringan selulosa longgar menghasilkan nata tidak lunak (alot). Sedangkan kadar air yang rendah memiliki serat tinggi sehingga air susah masuk pada jaringan selulosa yang rapat menghasilkan nata lunak (kenyal) [6].

\subsection{Uji Kadar Serat}

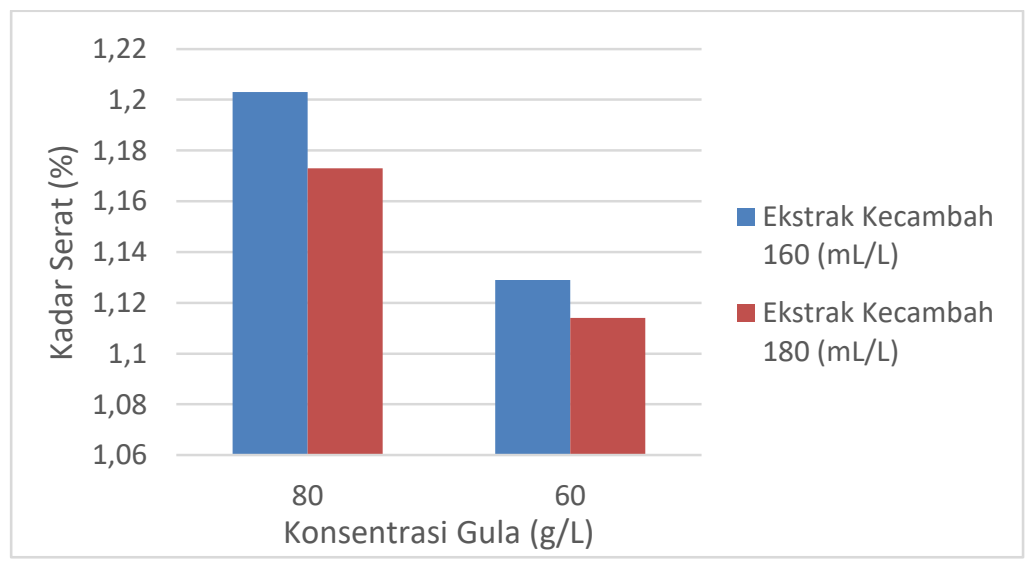

Gambar 2. Uji kadar serat pada Nata de Soya 
Berdasarkan pada gambar 2, hasil uji kadar serat dengan penambahan ektrak kecambah kacang hijau dan variasi gula menunjukkan bahwa kadar serat yang paling rendah pada konsentrasi gula $60 \mathrm{~g} / \mathrm{L}$ dengan penambahan ekstrak kecambah kacang hijau sebanyak $160 \mathrm{ml}$ dan $180 \mathrm{ml}$ yaitu 1,114\% dan 1,112\%. Kadar serat yang paling tinggi ada pada konsentrasi gula $80 \mathrm{~g} / \mathrm{L}$ dengan penambahan ekstrak kecambah kacang hijau sebanyak $160 \mathrm{ml}$ dan $180 \mathrm{ml}$ yaitu $1,203 \%$ dan $1,176 \%$.

Semakin besar kadar kecambah kacang hijau maka akan semakin tinggi kadar serat yang terdapat dalam nata. Hal ini dikarenakan Acetobacter xylinum merubah nitrogen dalam media menjadi sel baru sehingga banyak sel yang terbentuk menyebabkan serat nata lebih banyak [4]. Kadar serat yang dihasilkan pada media whey tahu dan ekstrak kecambah kacang hijau sebagai sumber nitrogen, memenuhi Standar Nasional Indonesia (SNI) 01-4317-1996 kriteria kadar serat yang dipakai yaitu kurang dari 4,5\%. Apabila kandungan serat lebih dari 4,5\%, akan menghasilkan nata dengan kekenyalan tinggi sehingga nata akan sulit terputus pada saat dikonsumsi [5].

\subsection{Uji Kadar Vitamin C}

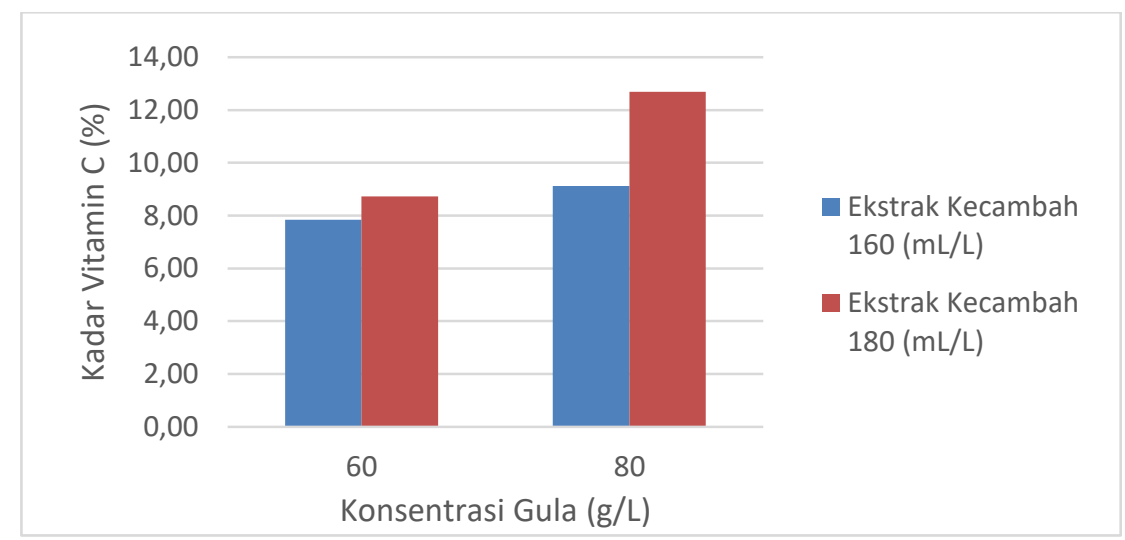

Gambar 3. Uji kadar vitamin c pada Nata de Soya

Berdasarkan gambar 3, didapatkan kadar vitamin c yang paling rendah dengan konsentrasi gula sebanyak $60 \mathrm{~g} / \mathrm{L}$ dengan penambahan ekstrak kecambah kacang hijau sebanyak $160 \mathrm{ml}$ dan $180 \mathrm{ml}$ yaitu 7,84\% dan 8,73\%. Kadar vitamin c paling tinggi pada konsentrasi gula $80 \mathrm{~g} / \mathrm{L}$ dengan penambahan ekstrak kecambah kacang hijau sebanyak $160 \mathrm{ml}$ dan $180 \mathrm{ml}$ yaitu 9,12\% dan 12,68\%. Berdasarkan grafik di atas dapat disimpulkan bahwa kurangnya pemberian ekstra kecambah kacang hijau dan fruktosa sebagai sumber nutrisi mengakibatkan kurangnya standar vitamin c yang sudah ditetapkan yaitu sekitar 73,6\% - 87,3\%. Hal ini dipengaruhi kerusakan vitamin c pada ekstrak kecambah kacang hijau yang dalam proses pembuatannya mengalami pemanasan yaitu dengan cara di masak sampai mendidih. 


\subsection{Rendemen}

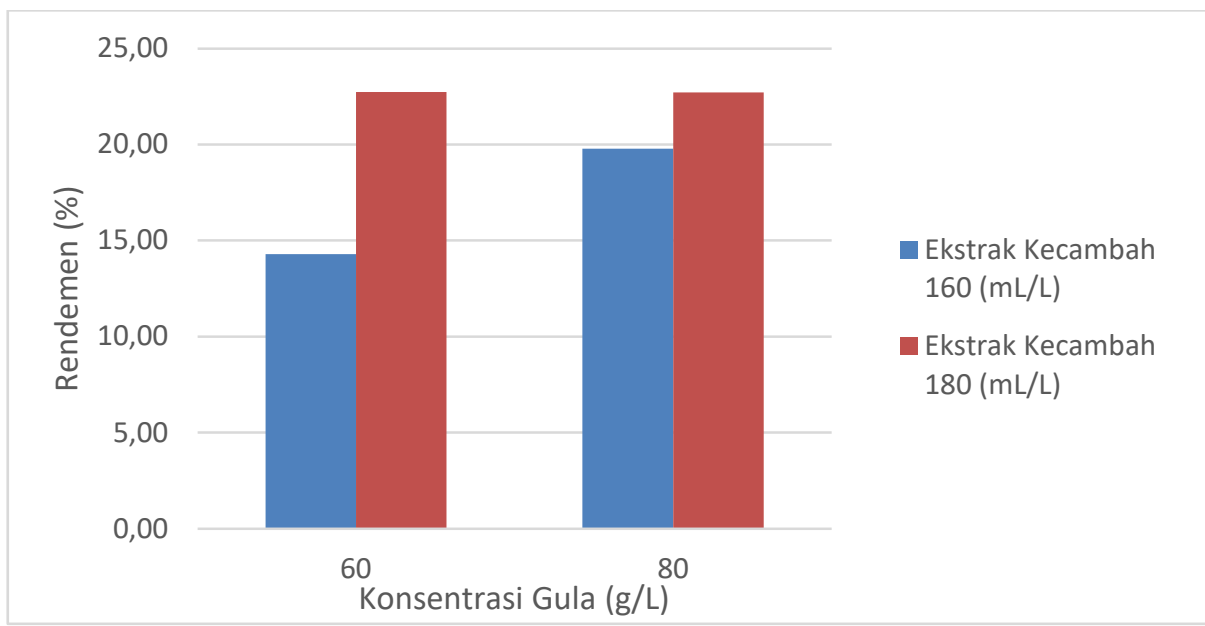

Gambar 4. Rendemen pada Nata de Soya

Berdasarkan gambar 4, hasil rendemen dengan penambahan ekstrak kecambah kacang hijau menunjukkan bahwa rendemen yang paling sedikit ada pada konsentrasi gula 60 g/L dengan ekstrak kecambah kacang hijau sebanyak 160 $\mathrm{ml}$ dan $180 \mathrm{ml}$ yaitu $14,29 \%$ dan $22,71 \%$, sedangkan rendemen yang paling banyak pada konsentrasi $80 \mathrm{~g} / \mathrm{L}$ dengan ekstrak kecambah kacang hijau sebanyak $160 \mathrm{ml}$ dan 180 ml yaitu 19,79\% dan 22,74\%. Penambahan ekstrak kecambah kacang hijau $180 \mathrm{ml}$ dan gula $80 \mathrm{~g} / \mathrm{L}$ menghasilkan nata yang lebih tebal. Dapat disimpulkan ketebalan nata berbanding lurus dengan konsentrasi ekstrak kecambah kacang hijau, maka semakin tingginya ekstrak kecambah menandakan ketebalan pada nata tinggi [9]. Hal lain yang mempengaruhi tinggi rendahnya rendemen yaitu lamanya fermentasi, karena semakin lama masa panen nata maka akan menghasilkan rendemen yang semakin tinggi dengan rerata 13 hari. Acetobacter xylinum tidak akan membentuk lapisan nata baru apabila melebihi batas waktu hal ini karena Acetobacter xylinum kehabisan nutrisi [10].

\subsection{Uji Ketebalan}

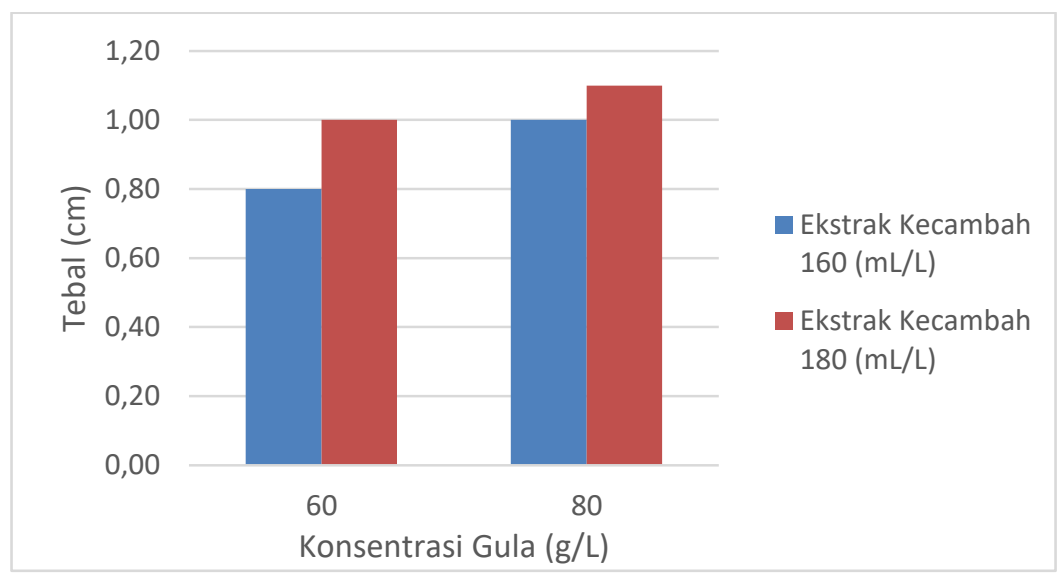

Gambar 5. Uji ketebalan pada Nata de Soya 
Berdasarkan gambar 5, hasil ketebalan dengan penambahan ekstrak kecambah kacang hijau dan variasi gula menunjukkan ketebalan terendah pada konsentrasi gula 60 g/L dengan ekstrak kecambah kacang hijau sebanyak $160 \mathrm{ml}$ dan $180 \mathrm{ml}$ yaitu $0,8 \mathrm{~cm}$ dan $1 \mathrm{~cm}$, sedangkan ketebalan tertinggi pada konsentrasi gula $80 \mathrm{~g} / \mathrm{L}$ dengan ekstrak kecambah kacang hijau sebanyak $160 \mathrm{ml}$ dan $180 \mathrm{ml}$ yaitu $1 \mathrm{~cm}$ dan $1,1 \mathrm{~cm}$. Tingkat ketebalan nata disebabkan karena banyaknya selulosa yang terbentuk, semakin tingginya rendemen mempengaruhi semakin tebalnya nata hal ini menyebabkan ketebalan nata akan berbanding lurus dengan rendemen.

Acetobacter xylinum memiliki kemampuan dalam menggunakan nutrisi pada media menjadi biomassa dan selulosa dapat memanfaatkan Acetobacter xylinum. Bakteri menghasilkan selulosa akan saling berikatan sehingga mampu membentuk lapisan nata yang tebal [1].

\section{KESIMPULAN}

Kadar serat pada Nata de Soya yang didapatkan telah sesuai SNI 01-4317-1996 yaitu kurang dari 4,5\%. Sedangkan hasil vitamin C, rendemen dan ketebalan menghasilkan hasil yang terbaik pada ekstrak kecambah kacang hijau $180 \mathrm{ml} / \mathrm{L}$ dan variasi gula $80 \mathrm{~g} / \mathrm{L}$. Hasil uji kadar air menghasilkan hasil terbaik pada ekstrak kecambah kacang hijau $160 \mathrm{ml} / \mathrm{L}$ dan variasi gula 60g/L.

\section{DAFTAR PUSTAKA}

[1] B. D. Hardianti and D. Wahyudiati, "Pengaruh Penambahan Jenis Gula Terhadap Berat dan Tebal Nata de Soya The effect of adding sugar to the weight and thickness of Nata de Soya," vol. 2, no. May, 2019.

[2] D. W. Sakti and G. Trimulyono, "Pengaruh Penambahan Limbah Cair Industri Tahu sebagai Sumber Nitrogen terhadap Kualitas Nata De Coco," Mipa Biol., vol. 8, no.

1, pp. 36-43, 2019, [Online]. Available:

http://ejournal.unesa.ac.id/index.php/lenterabio.

[3] Hastuti, "Pemanfaatan Ekstrak Kecambah Kacang Hijau Sebagai Sumber Nitrogen Alternatif Dalam Pembuatan Nata De Lerry," Pros. SNT, vol. -, no. 8, pp. 45-50, 2017.

[4] A. Patria, M. Muzaifa, P. Studi, T. Hasil, F. Pertanian, and U. S. Kuala, "Pengaruh Penambahan Gula dan Amonium Sulfat terhadap Kualitas Nata de Soya," J. Teknol. dan Ind. Pertan. Indones., vol. 5, no. 3, pp. 3-7, 2013, doi: 10.17969/jtipi.v5i3.1976.

[5] N. A. Yanti, S. Ambardini, W. O. Isra, and V. N. . Parakkasi, "Potensi Limbah Cair Tahu Sebagai Sumber Nitrogen Pada Produksi Selulosa Bakteri,” Bioma, vol. 5, no. 
1, pp. 9-17, 2020, [Online]. Available:

https://media.neliti.com/media/publications/326539-potensi-limbah-cair-tahusebagai-sumber-d2fe0bc6.pdf.

[6] A. M. Fifi Alfiana Nur, Andi Sukainah, "Pemanfaatan Kecambah Kacang Hijau dan Kecambah Kacang Kedelai Sebagai Sumber Nirogen dalam Pembuatan Nata de Pinnata Dari Nira Aren (Arenga Pinnata Merr),” vol. 5, pp. 61-66, 2019.

[7] Y. W. Silitonga, R. H. Lubis, K. Kunci, N. De Salacca, and P. Za, “AGRINTECH: Jurnal Teknologi Pangan dan Hasil Pertanian Volume 2 No Pengaruh Penambahan Ekstrak Touge Sebagai Sumber Nitrogen Alternatif Pada Pembuatan Nata De Salacca The Effect Of Addition Of Touge Extract As A Source Of Alternative Nitrogen For Making N," vol. 1, no. 1, pp. 2-5, 2018, doi: 10.30596/agrintech.v2i1.2460.

[8] W. M. Putri, "Pemanfaatan Limbah Cair Tahu sebagai Bahan Baku Pembuatan Nata De Soya," Sains Entrep., vol. 2, no. 1, pp. 1-5, 2017.

[9] N. Izzati, I. Irfan, and S. Rohaya, "Variasi Penggunaan Jenis Bahan Baku (Air Cucian Beras dan Air Kelapa) dengan Penambahan Ekstrak Tauge Terhadap Rendemen dan Mutu Nata," J. Ilm. Mhs. Pertan., vol. 4, no. 2, pp. 300-307, 2019, doi: 10.17969/jimfp.v4i2.10923.

[10] I. Putriana, S. Aminah, P. Studi, T. Pangan, U. Muhammadiyah, and S. Korespondensi, "Mutu Fisik, Kadar Serat dan Sifat Organoleptik Nata de Cassava Berdasarkan Lama Fermentasi Physical quality, Dietary Fiber and Organoleptic Characteristic from Nata de Cassava Based time of Fermentation," vol. 04, no. 07, 2013. 